\title{
Belphégor
}

\section{Translation as Counter-Memory: Mainmise and the Making of a Counter-Culture in Quebec}

\section{Carmen Ruschiensky}

\section{(2) OpenEdition}

1 Journals

\section{Electronic version}

URL: https://journals.openedition.org/belphegor/4367

DOI: 10.4000/belphegor.4367

ISSN: 1499-7185

Publisher

LPCM

\section{Electronic reference}

Carmen Ruschiensky, "Translation as Counter-Memory: Mainmise and the Making of a Counter-Culture in Quebec ", Belphégor [Online], 19-2 | 2021, Online since 04 January 2022, connection on 20 September 2022. URL: http://journals.openedition.org/belphegor/4367 ; DOI: https://doi.org/10.4000/ belphegor.4367

This text was automatically generated on 20 September 2022.

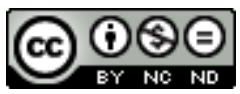

Creative Commons - Attribution-NonCommercial-NoDerivatives 4.0 International - CC BY-NC-ND 4.0 https://creativecommons.org/licenses/by-nc-nd/4.0/ 


\title{
Translation as Counter-Memory: Mainmise and the Making of a Counter-Culture in Quebec
}

\author{
Carmen Ruschiensky
}

1 Media culture in the 20th century has come to play an important role in the shaping of collective memory and identity. Media of all sorts - spoken language, books, photos, films, and so on - serve both as instruments for sense-making (mediating between the individual and the world) and as agents of networking (mediating between individuals and groups $)^{1}$. Magazines and periodicals are no exception. Like any form of cultural production, popular magazines can reflect the dominant culture or, on the contrary, serve as a point of reference for alternative collectives and imaginaries, or both. The prolific magazine culture of the 1960s American counter-culture provides a striking example of this latter centre-margin dynamic, as the movement initially emerged from an underground culture to gradually become co-opted by mainstream media ${ }^{2}$ and consumer society ${ }^{3}$.

While the American counter-culture reached its zenith toward the end of the decade with the publication of Theodore Roszak's The Making of a Counter Culture ${ }^{4}$ and the Woodstock music festival that same year ${ }^{5}$, the Quebec movement was just getting underway. Following the upheavals of the Quiet Revolution (1960-66) ${ }^{6}$ and the wave of sovereignist national affirmation that followed, Quebec was perceived by many to be the perfect milieu for the making of an alternative counter-cultural society ${ }^{7}$. The end of the 1960s saw the appearance of a number of counter-cultural periodicals in Canada and Quebec. Though not the first in Quebec, the magazine Mainmise, published in Montreal between 1970 and 1978, would prove to be the most influential and longlasting. Throughout the 1970s, Mainmise - from main meaning "hand" and mettre, "to put" (i.e. "hands on") - was the quintessential hub of the counter-cultural movement in Quebec.

3 Integrating perspectives from translation studies and memory studies, this chapter seeks to shed light on a unique example of 20th-century magazine culture in North 
America. It argues that Mainmise fostered the construction of a sought-after, alternative counter-memory through various forms of translation, in particular, through reidentification (cultural borrowing and linguistic transfer) and re-temporalization (the re-inscription of cultural references in a remembered past or utopic future). After outlining the concept of translation as counter-memory and its relevance in the Quebec context, I will first discuss the emergence of alternative collective references in postQuiet-Revolution Quebec to then concentrate on Mainmise as not only a locus of transnational, counter-cultural memory, but also as an indispensable reference for understanding Quebec's counter-culture as a whole.

\section{Translation as Counter-Memory}

4 Translation studies and memory studies scholars have explored, in different ways, the relation between translation and memory ${ }^{8}$. Once perceived as a marginal activity, translation has come to be seen as a fundamental act of human exchange ${ }^{9}$. Memories and meanings are translated (in the Latin sense of translatio, meaning "transfer," "carryover" or "displacement") between different languages and cultures. But in reactivating a cultural reference, translation is also an act of remembrance, an investment in an originating source that is reconstituted through its very reiteration. Though language contact and interlingual translation are still at the heart of translation studies, the turn to a broader cultural conception of translation has vastly enlarged the research terrain. Scholars of translation now study it in all its possible forms - across languages, genres and media, across cultures, nations and time, as an element of everyday communication in every imaginable context, even as an underlying social and cultural condition ${ }^{10}$. In a complementary fashion, recent memory studies research has been marked by a shift away from the national sites-of-memory approach of the $1990 \mathrm{~s}^{11}$ to a focus on transcultural, transnational and "travelling" memory. Astrid Erll, for example, proposes to conceive transcultural memory as "the incessant wandering of carriers, media, contents, forms, and practices of memory, their continual 'travels' and ongoing transformations through time and space, across social, linguistic and political borders" 12 . But even Nora's "memory site" concept already contained the seeds of a theory of translation, insofar as it describes lieux de mémoire as only existing "because of their capacity for metamorphosis, an endless recycling of their meaning and an unpredictable proliferation of their ramifications"13. Memory sites, in other words, are not simply reinterpreted; they are actively and symbolically recreated. Memory, like translation, is both a meaning-preserving and meaningmaking process ${ }^{14}$.

5 The concept of counter-memory is often linked to subordinated memory, suppressed histories, and the subversion of dominant narratives and discourses ${ }^{15}$. The reclaiming of suppressed history in this case functions to subvert the dominant culture from within while also reaffirming the legitimacy of previously effaced memories, identities or languages. A key example in the Quebec context is the revalorization of the French Québécois joual sociolect (derived from the pronunciation of the word cheval), which, in the wake of the 1960s Quiet Revolution, was elevated to a literary language in poetry, novels, music and, especially, on the stage in the works of Michel Tremblay and others. 16 
6 But counter-memory, as we argue here, can also be activated through the appropriation of alternative sources and references "from without," through various forms of cultural borrowing, transfer and translation. Translation as counter-memory, in this sense, is an active appropriation of otherness, whether through reification and abstraction ("cosmic consciousness") or through the borrowing of concrete cultural references (American, Indigenous, "Eastern," etc.), which often entails the (re)negotiation of specific intercultural relations and power dynamics. Countermemory can thus be conceived as a particular, subversive form or sub-category of transcultural or translated memory. The editors, contributors and translators of Mainmise, for example, sought out and embraced a "freak" otherness whose characteristic feature was precisely its transgressive potential and alterity - otherness for the sake of otherness, so to speak. While the affirmation of the French language and identity infused Mainmise's project and Quebec's counter-culture more broadly (indeed, the joual sociolect figures prominently), the movement still looked elsewhere to construct a new identity, primarily, though not exclusively, to American, Englishlanguage authors and artists, and trips to American hippy meccas like Haight-Ashbury in San Francisco or Greenwich Village in New York. These foreign references were appropriated and mediated through text, image, music and other forms of cultural transfer ${ }^{17}$. The term "translation" thus designates here a phenomenon that includes but extends beyond the concept of translation as one-way linguistic transfer to encompass different forms of rewriting, adaptation and remediation across languages, cultures, media and time.

\section{Alternative Print Media in post-Quiet-Revolution Quebec}

7 While the affirmation of Quebec's national francophone language and identity continued well beyond the strictly defined period of the Quiet Revolution (1960-1966), the post-Quiet Revolution years saw the emergence of new political movements (Marxist-Leninist, Black Power, Gay Power, Indigenous, women's and migrants' rights) and numerous alternative, avant-garde cultural and artistic undertakings. Indeed, the Nuit de la poésie in 1970, a legendary poetry event that attracted over 4000 spectators ${ }^{18}$, already united poets and artists of diverse political, aesthetic and cultural backgrounds. Montreal's Expo 67 also marked a decisive turning point, and the social and cultural changes that transformed Quebec from 1967 to the election of the sovereignist Parti Québécois in 1976 undoubtedly had as much of an impact on Quebec society as the Quiet Revolution itself ${ }^{19}$.

Quebec's counter-cultural movement arose over this period, partly as a result of the ideological transformations taking place but also due to the increased standards of living and education that accompanied these changes in Quebec, as elsewhere in North America $^{20}$. The new craze for counter-culture magazines emerged, in part, from this context. Across North America, more than 4000 counter-culture periodicals were published between 1965 and 1970, with an estimated readership of 15 million. The daily Los Angeles Free Press, founded in 1964 and often considered the first underground periodical in North America, had a print run in 1971 of 90,000 copies. The Realist printed 100,000 and, Rolling Stone Magazine, 300,000 ${ }^{21}$. The first Canadian counter-culture magazine was Georgia Straight, created in Vancouver in 1967 and inspired by the beatnik 
tradition of Kerouac and Ginsberg. Its print run quickly exceeded 60,000 copies, some of which found their way into the hands of Montreal readers every month. The first Québécois venture was the magazine Logos (1967-1973), initially published in bilingual editions then in English alone. Appearing in 1968, Le Voyage, more political than psychedelic, was a kind of francophone version of Logos $^{22}$.

9 At the same time, in Quebec, literary and political periodicals of all stripes entered onto the scene in great number -108 new publications appeared between 1970 and $1979^{23}$. Of note are the avant-garde literary journals $L a$ Barre du jour (1965), later renamed $L a$ Nouvelle Barre du jour (1977), Les Herbes rouges (1968) and Hobo-Québec (1973), described as sites of "rupture and continuity" that redefined the literary landscape and served as hubs for the young poets and writers of the period ${ }^{24}$. Feminist publications such as Québécoises deboutte! (1971-1974) and Têtes de pioche (1976-1979) were pioneers of feminist thought, the former oscillating between counter-cultural and Marxist-Leninist influences before adopting an activist orientation inspired by the national and social struggles taking place in Quebec and elsewhere in the world ${ }^{25}$. Sean Mills ${ }^{26}$ and David Austen ${ }^{27}$ have traced the emergence and evolution of the Black Power movement in Montreal, starting in the late 1960s, as represented in publications like Uhuru (1969-1970). This period also saw the beginnings of what would come to be known as écritures migrantes ${ }^{28}$, particularly with the founding of the journal Dérives published between 1975-1987 and bearing the subtitle: Tiers-Monde/Québec, une nouvelle conjoncture culturelle. A site of multicultural encounter and translation, Dérives was one of the "first discursive spaces in Quebec to have been infused with so many voices from elsewhere" ${ }^{29}$. All of these publications were hubs for emerging social movements, providing platforms for innovative cultural production but also social frames and networks conducive to building new memory sites and solidarities in their diverse but often overlapping political struggles.

\section{The Evolution of Mainmise}

10 Mainmise, as noted above, was the most important magazine associated with the emerging youth counter-culture movement in Quebec $^{30}$. Its editors initially drew inspiration from themes that formed the cornerstones of the American counter-culture movement - sex, drugs and rock ' $n$ ' roll - in order to imagine and (re)create an alternative vision of society. Mainmise was also a product of translation. As a member of the Underground Press Syndicate (UPS), the periodical had access to images and texts drawn from over 200 publications worldwide. For the amount of 25 dollars per year, any publication could join the UPS and receive copies of other members' publications. As Jean-Philippe Warren observes:

These exchanges gave members [of Mainmise] unlimited access to the bank of texts, images and photographs produced by this network of publications. The large number of French translations of texts previously published in American papers stemmed, in part, from one simple fact: free and easy access to a bank of bold and catchy texts that the Mainmisiens (the name that the magazine's creators gave themselves) had only to translate. ${ }^{31}$

11 The magazine's title itself (i.e. "hands on") derives from this idea of "access to" or, more specifically, "taking back," as one of its co-founders, Georges Khal, explains in an interview: 
While writing the manifesto, I came up with the name Mainmise, inspired by Abbie Hoffman: take back all the powers you've been robbed of, in other words, "put your hands on" what is yours, what you've given up to priests, doctors, politicians and specialists. So, for me, Mainmise was both about taking back - getting your hands on - and performing a kind of blessing. ${ }^{32}$

12 In addition to translating, Mainmise's editors and contributors also catalogued the American movement's key writings and music, adapted the graphic styles of its comics and periodicals, and served as a hub for an alternative social network, acting, in a way, as curators of the "freak" universe. ${ }^{33}$ Warren has described Mainmise as a sort of almanac for the global village that sought to comprise "a mosaic of diverse information, which, from the fabrication of snowshoes to grandma's remedies, and the best organic coops to legal advice, could contribute to building a more useful and community-based knowledge" 34 .

13 Mainmise evolved over three distinct periods, each of which saw changes in editorial direction, thematic content and structure, readership contribution, and visual style and format. The first 20 issues (1970-1973) were published in pocket-book form. From 1973 to 1975 (32 issues), Mainmise adopted an $8 \times 11$-inch magazine format and, from 1975-1978 (26 issues), a larger tabloid magazine format, modelled, like the French underground Actuel, after France's more mainstream Paris Match. Over its publication history, Mainmise's print run spanned 5000 to 30,000 copies.

The inaugural issue was launched in October 1970 and served primarily as the program for The Who's rock opera Tommy, a co-production with the Grands Ballets Canadiens performed at Montreal's Place des Arts. The opera's lyrics were fully translated into French by Mainmise and accompanied by interviews and photographs taken during rehearsals by the Office du film du Québec. Visually, the issue is marked by an eclectic, psychedelic style that would come to prevail over the next 20 issues (1970-1973), often creating the effect of a random collage of texts, drawings, photos and comics. ${ }^{35}$ Different sections sometimes overlap and extend over several pages in a non-linear fashion, and titles and contributors' names are often omitted. The main editorial director over this period was one of the magazine's co-founders (along with Georges Khal), Jean Basile Bezroudnoff. The latter, under the pseudonym Pénélope, also penned a number of articles and most of the music reviews. French translations of English texts also figure prominently. The first 20 issues include 29 individual translated texts, one entire issue structured as a collage of translated quotations (by Buckminster Fuller, Marshall McLuhan, Eldridge Cleaver, Jerry Rubin, Theodore Roszak, Allen Ginsberg and others), and several isolated quotes, translated song lyrics and adapted comic strips.

The second format (1973-1975) assumed a new look, focus and editorial direction (Georges Khal, Rolland Vallée and Michel Bélair). As in the first version of Mainmise, this period is also marked by an eclectic mix of textual and visual styles. The overall structure is more consistent, and more space is given to Quebec writing, music and art, including credited cover illustrations and comics by Quebec artists (which form the basis of two special issues). Carried over from the first format, local resources and practical information are a recurring theme (for example, how to grow your own pot or start a commune). Nonetheless, translations still make up a large part of the content (40 translated texts, plus song lyrics, quotes, interviews and comics), much to the dismay of some readers who, in their Lettres d'amour (letters to the editor), denounce the over-emphasis on American content. One letter signed "Don" complains of the "pathetic" reliance on American translation ${ }^{36}$. Another laments the lack of writing by 
"people from here, who have no means other than MM to express themselves". The shift to a more mainstream, less artistic design is also noted, with regret:

I really miss the old format, with its photos, its drawings filling the entire page, without limits in the space. From the moment I bought it, it already smelled of incense and pot. It was the work of an artisan; it had a soul. Now Mainmise feels to me like any other magazine, lost in the newsstand between the cigarettes and chewing gum..$^{37}$

The third format (1975-1978) saw an even more radical transformation and change in editorial direction (eventually assumed by Michèle Favreau), as well as a clearly identifiable fourth shift in the final 6 issues. In terms of design, structure and content, this new format is by far the most conventional of the three versions. It focuses almost exclusively on local music, arts, culture and interviews ${ }^{38}$. Photos rather than illustrations grace the magazine's covers, the first nine of which all feature popular Québécois musicians: Charlebois, Beau Dommage, Louise Forestier, Harmonium, Plume, Les Séguin, Dionysos, Félix Leclerc and Clémence Desrochers. The addition of a "Dossier Province" highlights this re-centering of Quebec content, as does the reduction in the number of translations. There are 13 translated texts overall and, for the first time, translations are often altogether absent. Issues 72-78 include, along with Mainmise, the subtitle Rezo on the cover. The new Rezo section features contributions from different parts of the alternative reseau across Quebec. This third format is less experimental and radical than the previous two, both in form and content. The last issues, in particular, espouse a more responsible and focused approach to "rebuilding the movement" through networking and community.

\section{Modes of Translation: Past, Present and Future}

Despite the waning interest in translation towards the end of the magazine's publication history, the central role that it played in Mainmise, if only in terms of quantity, seems self-evident. Among the 82 individual, often lengthy, translated texts identified over 78 issues, Mainmise translated at least 68 of these from English into French. We say "at least" because some of the Mainmise translations appear to integrate previously existing translations. Indeed, line-by-line, source-to-target translations tend to be the exception. Most of the translated texts are excerpts, compilations or abridged versions that include adapted content and sometimes translators' commentaries integrated into the body of the text (often without clear attribution of authorship). In addition to these individual translated texts, translated quotes of varying lengths, adapted diagrams, ads, comics, and so on, are sprinkled throughout. Moreover, many of the original French-language contributions rely heavily on foreign or alternative sources or focus on the movement's connection to other time periods or "zones" (acid trips, tantric sex, meditation, etc.). Taken together, these diverse interpretive processes constitute modes of translation that range from the imitation and transposition of texts or practices to different forms of adaptation and appropriation ${ }^{39}$. In Mainmise, these translational dynamics are marked by what might be described as an experimentation with different collective identities and memories - the construction of a countermemory through re-identification and re-temporalization. As we shall see, the "identitary translations" in Mainmise primarily foreground 1) American (countercultural), 2) marginalized (Gay, Indigenous and women's), and 3) exotic (cosmic, "Eastern," or "freak") identities. The "temporal translations" draw on: 1) ancient, 
biblical and medieval sources, 2) French-Canadian history and survivance, and 3) millenarian, utopic and futuristic themes.

\section{Re-identification}

18 With respect to the Mainmisiens' identification with alternative collective references, the American counter-culture was by far the most prevalent source of inspiration. The magazine's founders, Georges Khal and Jean Basile, drew on their shared passion for the American authors and music. Khal describes immersing himself, during a threemonth stay in New York's East Village, in the American underground press, Playboy interviews, the works of Timothy Leary and Buckminster Fuller, and Stewart Brand's Whole Earth Catalog ${ }^{40}$, among others ${ }^{41}$. The latter would become the model for Le Répertoire québécois des outils planétaires - "Yes, Freaks, my co-believers! We're finally going to have a Whole Earth Catalog in French" ${ }^{42}$-, which was eventually published by Mainmise as a separate volume in 1977. A 1972 special issue based on a group trip to San Francisco provided an extensive overview of the local scene there, incorporating several paraphrased and partially translated interviews. Why San Francisco? "Because there are ten years of acid in San Francisco. Because San Francisco is a Mecca for us. That's where our movement was born. That's where our music comes from" ${ }^{43}$.

American texts translated into French include excerpts from Abbie Hoffman's Woodstock Nation ${ }^{44}$ and Rasa Gustaitis' Turning $\mathrm{On}^{45}$, translated articles from Esquire, The Los Angeles Free Press, Playboy (Alan Watts), Scientific American (Lester Grinspoon), and comics by Ron Cobb, Rick Veitch and Robert Crumb, among others, translated into joual. A 1973 issue includes a long interview with Ken Kesey (of One Flew Over the Cuckoo's Nest fame) conducted and translated by Linda Gaboriau on a visit to the author's Springfield farm in Oregon ${ }^{46}$. Kesey recounts anecdotes from the history of the $1960 \mathrm{~s}$ American west-coast psychedelic movement, including meetings with Bob Dylan, Jim Morrison, The Beatles and Janis Joplin, road trips (and acid trips) with Neal Cassady and other members of the Merry Pranksters, and a rather strange encounter in Palo Alto involving a group of Stanford professors, Eldridge Cleaver and Jean Genet. The interview reads like an insider's testimony on the birth of the movement, straight from the horse's mouth.

The next two periods of Mainmise would see lengthy translations, spread over several issues, of works by other key American counter-cultural figures. Michel Chevrier, whose Chronique de la Mère Michel was the longest-running column in the magazine, translated Joanna and Timothy Leary's NeuroLogic ${ }^{47}$ and Rick Strauss' How to Win Games and Influence Destiny: A Manual for Apprentice Gods ${ }^{48}$. He also co-translated (with Christian Allègre, Michel Bélair, Denis Côté, Clément Despelteaux, Georges Khal, Robert Tétreault, and "John") Leary's Terra II: The Starseed Transmission", which is, in itself, framed as a kind of translation, an extraterrestrial "transmission." Serge Laliberté translated Buckminster Fuller's 1968 Operating Manual for Spaceship Earth ${ }^{50}$, and Georges Khal translated excerpts from Stewart Brand's II Cybernetic Frontiers: Both Sides of the Necessary Paradox ${ }^{51}$. Issue 47 includes a "rapport-collage" on the Rencontre internationale de la contre-culture that was held in Montreal from April 21-27 in 1975. It features a translated interview with two veritable stars of the American movement - William Burroughs and Allen Ginsberg - who participated in the conference ${ }^{52}$. 
21 Over the course of the magazine's evolution, Mainmise's indebtedness to and almost veneration of many of these American figures and sources remained fairly constant, though it was often tempered by calls from readers and contributors to better "quebecizer," or assimilate, the content. As Victor-Lévy Beaulieu observed:

If I look a little closer at what happened in Quebec from an official counter-cultural point of view, I notice one thing right off the bat. It's that our counter-culture is, despite my respect for Mister Memmi, mimetic [...] the folks at Mainmise seemed to have been incapable of "quebecizing" the thing, in other words, of integrating the whole American counter-cultural phenomenon, of giving it an evolution and a meaning that would have really mattered to us. ${ }^{53}$

While the counter-cultural movement already sought to carve out an alternative space in mainstream society, Mainmise's contributors also identified with groups that were seen to be marginalized, both within the counter-culture and beyond. Links between counter-cultural figures and the Black Power movement, for example, are occasionally highlighted, along with images (Eldridge Cleaver photographed in Algeria with Timothy Leary), news stories, or translated quotes by Black Panther leaders (Bobby Seale, Malcolm X and Huey Newton). The avant-garde poet Denis Vanier, in his role as president and "practically sole member of the Québécois White Panthers," is described as a pioneer of the Quebec counter-cultural movement ${ }^{54}$. In the special issue dedicated to San Francisco, the authors refer to the Weathermen, socialists, the Yippies, Women's Lib, the Gay Front and the Black Panthers as "all forevermore linked by vibes, the vibes of the counter-culture" 55 .

But in terms of the most translated and referenced content, gay, Indigenous and women's groups figure most prominently. From as early as the second issue, Mainmise is touted as the "Québécois organ of international rock, magical thinking and gay sçavoir [sic.]" ${ }^{56}$ These first issues include a text translated from The Los Angeles Free Press on cinema and Gay Power ${ }^{57}$, an article titled "Pour un Front gay à Montréal" ${ }^{58}$, and, most importantly, a lengthy but abridged translation of Carl Wittman's A Gay Manifesto ${ }^{59}$, translated into French as Manifeste du Front de libération homosexuelle. While Mainmise's French translation of this text has been critiqued for certain biases and omissions ${ }^{60}$, partial and abridged translations, as already noted, were quite common in Mainmise. Translations, even longer ones, often spanned entire issues or more than one issue, and drew on information from diverse sources. Though individual translators may have set out to create accurate translations, the early issues of the magazine were dominated by a fragmented, psychedelic style that most likely affected how translations were presented.

24 A new column titled “La vie gay' was introduced in issue 21 (1973), which, after issue 29 changed to the "Page gay." These often-short, one-page entries include translated interviews ${ }^{61}$, book reviews (Homosexuel? Et Pourquoi pas! by Jean LeDerff) ${ }^{62}$, event coverage (Les sœurs en congrès lesbian conference in Los Angeles) ${ }^{63}$, letters (Pierre Falardeau writing to Canadian Prime Minister Pierre Trudeau on gay rights) ${ }^{64}$, news reports (the censuring of Toronto's gay magazine The Body Politic in 1973), and opinion pieces, such as "Rôle prophétique de l'homosexuel dans notre société judéochrétienne" 65 and "Un front homosexuel québécois de libération" 66 , among others.

Indigenous sources and authors are also foregrounded. The Mainmisiens were inspired, in part, by what they saw as the Indigenous connection to nature, which they associated to their own back-to-nature movement. A section titled "Les Indiens parlent (parfois)" (1973) includes excerpts of 19th-century speeches by 11 Indigenous leaders ${ }^{67}$. 
Starting in issue 28, a column by Raynold Lortie titled "L'Indien" is introduced. The column continues over 10 issues and includes reports on trips to James Bay ${ }^{68}$, a review of a special issue of Recherches amérindiennes au Québec ${ }^{69}$, and an interview with filmmaker Arthur Lamothe, "Les indiens et le péril blanc" ${ }^{70}$. The first version of the column features an excerpt from the French translation of The Unjust Society by prominent Cree activist Harold Cardinal, who writes: "We offer our culture; we offer our heritage. We know it is different from yours. We are interested in your culture and heritage; we want you to discover ours" ${ }^{71}$. According to the column's author, "all the freaks who are advocating a return to nature have already begun to understand this message [...] In the months to come, I'll be tripping on this message with you" ${ }^{\prime 2}$. While the "Indian" is subject to a certain othering in some of these pieces, a number of Mainmise's contributors and readers expressed great interest in learning more about Indigenous languages, laws, culture and history, which they saw as being linked to their rejection of mainstream society and forging of new identities and possibilities.

The Mainmisiens also wrote and translated texts on a wide range of topics related to women's issues and emerging feminist movements around the world. Sometimes these overlap with writings on the gay movement, calling both men's and women's gender roles into question. Other texts focus on women's health and sexuality ${ }^{73}$ or highlight work by women $\operatorname{artists}^{74}$. Issue 21 features a translated excerpt of Yoko Ono's essay "The Feminization of Society"75. A "Spécial bonnes femmes" edition (1974) is devoted entirely to women's issues and identity. It includes an interview with French feminist Monique Wittig, originally published in Actuel, an article on the women's movement in Montreal, a listing of women's resources, and an interview with Germaine Greer and Kate Millet, conducted and presumably translated (from English into French) by MarieFrance Moore. The third format, under the editorial direction of Michèle Favreau and, later, Paule Lebrun, would see an even greater emphasis on feminism and women's art, writing and resources, interests that often overlapped with the magazine's renewed focus on networking, community and environmental issues.

The last category of identitary references in Mainmise, described here as "exotic," is perhaps the most ambiguous, since it is based on identities borrowed from diverse and sometimes newly invented identitary groups. The counter-cultural appropriation of "Eastern" or "oriental" culture is well-known. The American hippies recounted their travels to India or Tibet, learned yoga and meditation, and adopted (or became) gurus. These sources and practices were also embraced by the Mainmisiens. Early issues include quotations from the I Ching, a translated chapter of Be Here Now, Remember by Baba Ram Dass ${ }^{76}$, a.k.a. American author Richard Alpert, who popularized Eastern spirituality in the United States, and translated excerpts from Carlos Castaneda's The Teachings of Don Juan ${ }^{77}$. Though the latter was based on the alleged Yaqui Indigenous culture from northern Mexico, part of its appeal in the counter-culture movement was its focus on alternative spiritual practices, such as shamanism and the use of psychoactive drugs.

28 The "cosmic" or "freak" references in Mainmise tend to fall into two main categories, based on either universal, even intergalactic, imaginaries, or on a specifically Québécois mutant identity. In a 1973 article titled "Les manuels pratiques du nouveau Noé ou comment bâtir son arche en paix et chez soi," Georges Khal presents a list of readings for an identitary makeover, including books by Robert Graves, Erich Neumann, Wilhelm 
Reich, Friedrich Nietzsche and others. Khal espouses a redrawing of the planetary and cosmic map:

We have to reopen the history of all the religious, scientific, political, social, mythological and psychic dogmas, search the content of everything that has been systematically suppressed [...] operate the great Universal Synthesis, MUTATE, become, literally, MUTANTS. ${ }^{78}$

Khal continues this line of thought, describing the magazine Mainmise itself as an "operating manual" 79 for constructing a new cosmic, mutant identity:

We have to understand, once and for all, the tremendous importance of the years to come: it is no longer a question of righting wrongs or technological progress. There is now but one single cause: TRANSFORMATION, MUTATION. ${ }^{80}$

Issue 28 is "devoted to mutants" and includes a questionnaire addressed to Mainmise's "co-mutant" readers (1973). Charles Gosselin elaborates here on Khal's ideas, but centered, instead, on how to build "Kébek" ${ }^{81}$. This shift in focus or, rather, tension between a universal freak identity and a "Kébécois mutant" one, becomes a recurring theme of Mainmise in its quest "to constitute a mutant race of Homo Quebecquensis or Homo Psychedelensis" ${ }^{82}$. The mutant-kébécois identity is sometimes tied to the notion of Quebec playing a special role in the making of the counter-culture, due to its unique geographical situation and, especially, its minority French-language status in North America, which already set it apart. According to the Mainmisiens, Quebec was more than one alternative among others, it was the alternative ${ }^{83}$. As Jean Basile writes:

For us, Quebec's basic identity is not defined by a political option or an economic graph but, rather, by the sum of all of our energy stations. The strategy of Quebec's counter-culture is, in one form or another, to transform all of Quebec into an immense energy station ${ }^{84}$.

\section{Re-temporalization}

Over its publication history, Mainmise looked not only to other identities but also to other time periods to construct a new collective memory that would run counter to that of the current, mainstream society. The most recurring temporal references draw on three main sources: ancient and medieval history, the French-Canadian past, and utopic visions of the future. In the pages of Mainmise, these time periods sometimes overlap, combining, for example, biblical or millenarian predictions of catastrophe (that would herald in a future utopia), or linking French-Canadian survivance to the survival of humanity and the planet as a whole (in the face of ecological disaster, fascism, technocracy, etc.). This mixing of time periods entailed translating different experiences across time. The Mainmisiens, for example, describe their movement as being part of a "paleocybernetic era": "We are, in other words, the cavemen of the flamboyant technology of our electronic future. Everything is happening so quickly that we are already, perhaps, in the Middle Ages of the cybernetic era" ${ }^{85}$.

Biblical and medieval references are particularly prevalent over the second period of Mainmise. As we have seen in the previous section, George Khal's advice for creating a vehicle of cosmic transformation is linked to the biblical story of Noah's Ark. By extension, the children of the counter-culture are said to be the "new Adams and Eves" and "first universal humans in History" 86 . A 1974 article by Michel Bélair titled "Kessé la Kabbale" is dedicated to an exploration of the Jewish mystical tradition, complete with charts, diagrams and decodings of the Hebrew alphabet (citing Carlos Suarès and 
Gershom Scholem). Bélair's interest in the subject is based on what he sees as a filiation of thought across the ages, from "names as different as YHWH, Adam and Timothy Leary, to techniques as distant as the I-Ching, the Tarot and [Leary's] NeuroLogic" 87 . Another article by Bélair from this period includes an interview with a present-day stonemason named Fred, who is described as the "prophet-mason of old Quebec" 88 . Fred seems to inhabit different time periods, emits an atmosphere of "temporal odours":

He's a sort of alchemist [...] as though contact with the rock he shapes into arches and vaults using techniques rooted in the art of the Middle Ages, constituted his laboratory of transformation. Fred has something of a biblical prophet about him [...] As though in handling the objects from another age, a pocket of space-time could be suddenly transplanted into the present. ${ }^{89}$

In a similar vein, Jean Basile describes the counter-cultural "gothic cathedral" as being built not with stone or physical material but with airwaves, radiowaves and, eventually, brainwaves. "Everything we create," he writes, "is literally a minute detail of this dazzling cybernetic cathedral":

[We are] like our direct ancestor, the sculptor-mason of the Middle Ages [...], who with a simple hammer and chisel carved out the lips of a smiling angel at Reims, without ever seeing, or even dreaming of seeing, the last cornerstone on the last bell tower [...] We will better understand the type of Society we are building, and the place we occupy in it, if we refer to the structures of the Middle Ages while adding our own dimension to it. .0

Other examples include references to Hieronymus Bosch's 15th-century painting The Garden of Earthly Delights, which is compared to Stanley Kubrick's film 2001: A Space Odyssey (1968), and Robert Charlebois' then-forthcoming album Solidaritude (1973), which is said to include songs "reminiscent of the Middle Ages but presented in a modern way"

Though Quebec's counter-cultural movement, like the Quiet Revolution before it, sought to break with the immediate past, French-Canadian history is, somewhat paradoxically, abundantly revisited and re-interpreted in Mainmise. This tension between rupture and continuity may be related to a "memorial displacement" arising from a sense of shame associated with the Duplessis era and the Grande Noirceur ${ }^{92}$. From this point of view, the French-Canadian paradigm of survivance, which espoused a fidelity to origins and the preservation of the French language, culture and traditions, would also be rejected as a defeatist and retrograde worldview ${ }^{93}$. The Mainmisiens, however, gave survivance a new meaning by looking to lessons from the past while also expanding the concept of survival to encompass a more eclectic, universal worldview:

Everything in our cultural history attests to the universal propensities of our culture. We already have all the historical elements that define the new culture of the new generation: from our coureurs des bois (our hippy great-grandfathers!) to the newcomers and iconoclasts in our Cegeps and universities, and all the ambivalent phases of colonialism, the both sad and happy fate of minorities, the matriarchy, clergyism, joual, beatniks and the alienated no-culture-no-language-ofour-own non-identity. ${ }^{94}$

Really surviving meant adapting, as quickly as possible, "to the great changes taking place" and "weaving the web of the planetary nervous system" 95 . This is what poet Paul Chamberland, in his regular Mainmise column, called "extreme survival" in a series of poems, some of which were included in a later publication of the same name: Extrême survivance, extrême poésie (1978). 

preoccupied with survival, in the more practical, literal sense of the term. Drawing once again on French-Canadian history, two issues of Mainmise (22 and 23) devote considerable space to a reprinting of Le Livre du Colon: Recueil de renseignements utiles, originally published by the Ministère de la Colonisation de la Province du Québec in 1902 and serving as a practical guide for newly established settlers in Quebec at the turn of the 20th century. This detailed guide was considered a useful resource for Mainmise's readers and contributors at a time when many of them were experimenting with rural communes and self-sufficient, back-to-nature lifestyles. The text details how to clear a plot of land, build a house, plant and harvest crops, attend to livestock, and so on - useful information for the counter-cultural "néo-colons":

Spring arrives and, with it, the urge to get back to the countryside. But it's not so easy. The best way, perhaps, is to go back a few decades. This "Livre du colon" was specially written, at the turn of the century, for those arriving in Canada and wanting to settle on a plot of land. It contains virtually all the basic elements for a rural installation. The freaks' situation is hardly different from that of the first settlers: lots of good will, a touch of naiveté... and very little money. ${ }^{96}$

connection or re-connection to the land, itself a central theme of French-Canadian survivance, often finds its place in the pages of Mainmise, for example in the "Québécologie" book review section, or in the MainMiseMatane (Terre che-nous [sic.]) insert, with dispatches from Michel Bélair and other freaks who, "driven by a certain longing for the countryside" ${ }^{97}$, had left the city to set up communes across rural Quebec.

While some contributors to Mainmise were looking to the past, seeking a return to socalled simple rural living, others were more focused on the future, through their interest in new technologies and new communication theories, like McLuhan's "media ecology," Bateson's "cybernetics," and Stevens' "electronic social transformation." Space travel, extra-terrestrials and science fiction are recurring themes. Kubrick's 2001: A Space Odyssey is omnipresent, as is the persistent emphasis on mutation and transformation. The third most prevalent temporal reference in Mainmise is indeed futuristic and utopic but, more often than not, couched in terms of an end-times apocalyptic scenario, followed by a rebirth or transition into a newly evolved cosmic consciousness. The utopia that emerges is, in other words, a typically millenarian one. This is evident from the very first issue, wherein Basile (Pénélope) plainly states that the goal of Mainmise is utopia, which is also said to depend on translation:

In Quebec, U.T.O.P.I.A takes on a particular aspect. For us, the Québécois identity is quite naturally inscribed in the great movement of utopic liberation that is steering us toward the year 2001. While we are INFORMERS, we must also be TRANSLATORS. 98

The impending doom that would herald in this utopia is announced soon after: "We know the paranoia," writes Pénélope, "of the end of the world: the speedfreaks, the year 2000, the earthquakes in Frisco, the great Cycle, the repression"99. The fifth issue of Mainmise is divided, accordingly, into 2 parts, with a part 1 focusing on the END, and a part 2, on the BEGINNING - reversing the normal, temporal order. Likewise, in a series of articles spread over 4 issues, Charles Gosselin develops the Noah's Ark theme, with an emphasis on end times and utopic transformation:

If you do not feel with your entire body and the entire force of your intuition that the planet is on the verge of a gigantic ecological, psychic and political catastrophe, 
read no further [...] All of man's physical and psychic rot, accumulated over thousands of years on this poor Earth, is going to one day hit us in the face. ${ }^{100}$ counter-culture already in decline, especially in the United States. Richard Nixon has just been re-elected in a landslide victory. Jerry Rubin is a traitor. Bob Dylan is a millionaire who invests in the arms industry. There has always been a love-hate relationship between the Left and the counter-culture movement. There has always been a love-hate relationship between Canada (and by extension, Quebec) and the United States. Tom Forcade, the president of the UPS, has declared what everyone in the movement is afraid to say out loud: that the heroes of the counter-culture are dead. In a 1973 article titled "Yin/Yang: Un entretien cyclique avec Georges Khal et Jean Basile sur la catastrophe qui attend le monde," Mainmise's two co-founders reflect on the state of the counter-culture movement, as well as on Québécois identity, which, for them, was never about Kamouraska, the Automatists, a political party, or even language. Basile argues that "when the heroes are worn out, the counter-culture is dead, or at least moribund." Georges Khal disagrees:

The counter-culture is extremely flexible. Flexibility is one of its postulates. When the heroes are tired, the man in the street steps in. This makes for fewer headlines, but it's just as effective. It's not a question of death, on the contrary. The real feeling one has looking at the American scene, is that the pendulum continues its eternal swing. ${ }^{104}$

\section{NOTES}

1. Astrid Erll and Ann Rigney (eds.), Mediation, Remediation and the Dynamics of Cultural Memory, Berlin, Walter de Gruyter, 2012, p. 1.

2. Karim Larose and Frédéric Rondeau (eds.), "Introduction", La contre-culture au Québec, Montréal, Presses de l'Université de Montréal, 2016, p. 9. 
3. Jean-Philippe Warren and Andrée Fortin, Pratiques et discours de la contre-culture au Québec, Québec, Septentrion, 2015, p. 13.

4. Theodore Roszak, The Making of a Counter Culture: Reflections on the Technocratic Society and its Youthful Opposition, New York, Doubleday, 1969.

5. Karim Larose and Frédéric Rondeau, art. cit., p. 9.

6. Quebec's Quiet Revolution [Révolution tranquille] (1960-1966) was a period of intense sociopolitical change and government-led reforms that reaffirmed French-Canadian (Québécois) identity, rejected the authority of the Catholic Church, and invested in State-run education. It spawned a national sovereignist movement that eventually led to two referendums on Quebec's separation from Canada.

7. As Jean-Philippe Warren and Andrée Fortin observe: "Marshall McLuhan did not hesitate to describe the Québécois people as 'hippies' (cited by Marcel Rioux 1987, 19), and Linda Gaboriau affirmed in all seriousness that 'Quebec as a whole could be considered the underground of Canada' (Gaboriau 1970, 98). As for Victor-Lévy Beaulieu, he declared in a similar vein: 'Quebec, by its very definition and in general, is counter-cultural [...] everyone of us living here is countercultural' (Beaulieu 1973, 365)." Jean-Philippe Warren and Andrée Fortin, Pratiques et discours de la contre-culture au Québec, op. cit., p. 11.

8. Relevant studies include, among others: Sherry Simon, Translating Montreal: Episodes in the Life of a Divided City, Montreal, McGill-Queen's University Press, 2006; Sherry Simon, Cities in Translation: Intersections of Language and Memory, London and New York, Routledge, 2012; Siobhan Brownlie, Mapping Memory in Translation, London, Palgrave Macmillan, 2016; Michael Rothberg, Multidirectional Memory, Stanford, Stanford University Press, 2009; Chiara De Cesari and Ann Rigney (eds.), Transnational Memory: Circulation, Articulation, Scales, Berlin and New York, De Gruyter, 2014; Lucy Bond and Jessica Rapson (eds.), The Transcultural Turn. Interrogating Memory Between and Beyond Borders, Berlin and New York, De Gruyter, 2014; Lucy Bond, Stef Craps and Pieter Vermeulen (eds.), Memory Unbound. Tracing the Dynamics of Memory Studies, New York, Berghahn Books, 2017.

9. Susan Bassnett, Translation Studies, third edition, London and New York, Routledge, 2002, p. 1.

10. Sherry Simon, Translating Montreal, op. cit., p. 9.

11. See Pierre Nora, Les lieux de mémoire, 7 vols., Paris, Gallimard, 1984-92.

12. Astrid Erll, "Travelling Memory", Parallax, vol. 17, no 4, 2011, p. 11.

13. Pierre Nora, "Between Memory and History: Les Lieux de Mémoire", Representations, no 26, special issue, Memory and Counter-Memory, 1989, p. 19.

14. Siobhan Brownlie, Mapping Memory in Translation, op. cit.

15. See Michel Foucault, Language, Counter-Memory, Practice, trans. Donald. F. Bouchard and Sherry Simon, Ithaca, Cornell University Press, 1977.

16. Louise Ladouceur describes joual as an oral language characterized by striking regionalisms specific to Quebec that juxtaposes "archaisms, pronunciations, and turns of phrase from early colonial times with expressions borrowed from Indigenous languages and anglicisms derived from the dominant English culture": Louise Ladouceur, "Michel Tremblay's Les belles soeurs in Toronto: Theatre Translation and Bilingualism", in Kathy Mezei, Sherry Simon and Luise von Flotow (eds.), Translation Effects: The Shaping of Modern Canadian Culture, Montréal, McGill-Queen's University Press, 2014, p. 307. Though joual, a working-class sociolect, was widely integrated into "highbrow" culture and still has its place in contemporary Québécois literature, its 
status has been subject to intense debate in both literary and political circles. See Karim Larose, La langue de papier. Spéculations linguistiques au Québec, Montréal, Presses de l'Université de Montréal, 2004.

17. Carmen Ruschiensky, "Mainmise sur la contre-culture américaine : la traduction comme véhicule de transfert culturel", in Élyse Guay and Rachel Nadon (eds.), Relire les revues québécoises : histoire, formes et pratiques, Montréal, Presses de l'Université Montréal, 2021, pp. 217-241.

18. Pascal Brissette, “Que sont nos nuits devenues ?", Québec français, no 171, 2014, p. 55.

19. Jean-Philippe Warren and Andrée Fortin, Pratiques et discours de la contre-culture au Québec, op. cit., p. 7.

20. Jean-Philippe Warren, "Fondation et production de la revue Mainmise (1970-1978)", Mémoires du livre/Studies in Book Culture, vol. 4, no 1, 2012, par. 5. Online, URL: https:// www.erudit.org/fr/revues/memoires/2012-v4-n1-memoires0385/1013326ar/.

21. Ibid.

22. Ibid., par. 9

23. Élyse Guay, "La Revue Dérives (1975-1987) et l'écriture migrante : introduire le tiers dans la littérature québécoise," Master's Thesis, Université du Québec à Montréal, 2015, p. iv; Andrée Fortin, Passage de la modernité. Les intellectuels québécois et leurs revues, Sainte-Foy, Presses de l'Université de Laval, 2006 [1993].

24. Michel Biron, François Dumont and Élisabeth Nardout-Lafarge, Histoire de la littérature québécoise, Montréal, Boréal, 2010 [2007], p. 490; Élyse Guay, "La Revue Dérives (1975-1987) et l'écriture migrante... », op. cit., p. 22.

25. Élyse Guay, "La Revue Dérives (1975-1987) et l'écriture migrante... », op. cit., p. 54.

26. Sean Mills, The Empire Within: Postcolonial Thought and Political Activism in Sixties Montreal, Montréal, McGill-Queen's University Press, 2010.

27. David Austen, Fear of a Black Nation: Race, Sex, and Security in Sixties Montreal, Toronto, Between the Lines, 2013.

28. See Clément Moisan and Renate Hildebrand, Ces étrangers du dedans. Une histoire de l'écriture migrante au Québec (1937-1997), Québec, Nota bene, 2001.

29. Élyse Guay, "La Revue Dérives (1975-1987) et l'écriture migrante... ", op. cit., p. iv.

30. See also Marie-France Thériault, "Mainmise: Trois ans de recherche", Mainmise, no 23, 1973, pp. 16-49 and "Un ouvrage simple sur l'homosexualité", Mainmise, no 23, 1973, p. 55; Marie-France Moore, "Contre-culture et culture politique au Québec. Une analyse de contenu de la revue Mainmise”, Master's Thesis, Université du Québec à Montréal, 1975; Jules Duchastel, "Mainmise : la nouvelle culture en dehors de la lutte des classes?", Chroniques, nos 18-19, 1976, pp. 38-58; Jean-Philippe Warren, "Fondation et production de la revue Mainmise (1970-1978)", art. cit; Jean-Philippe Warren, "Mainmise: Un almanach du village global", in Karim Larose and Frédéric Rondeau (eds.), La contreculture au Québec, Montréal, Presses de l'Université de Montréal, 2016, pp. 415-432; and Felicity Tayler, "Mainmise, 1970: Situating Québec within Planetary Geographies", Mémoires du livre/Studies in Book Culture, vol. 10, no 1, 2018. Online, URL: https:// doi.org/10.7202/1055410ar.

31. Jean-Philippe Warren, "Fondation et production de la revue Mainmise (1970-1978)", art. cit., par. 18. All translations in this article are mine unless otherwise noted. 
32. Khal, Georges, "Les origines de Mainmise", Paspied, 10 August, 2010 [2004], par. 28. Online, URL: http://paspied.boutotcom.com/2010/08/10/historique-rapide-desorigines-de-mainmise/.

33. Carmen Ruschiensky, "Mainmise sur la contre-culture américaine...", art. cit. Mainmise was certainly not the first vehicle of American cultural transfer in Quebec. Jean Morency, for example, has traced the American influence on Quebec novels starting in the mid-nineteenth century : Jean Morency, "L'américanité et l'américanisation $\mathrm{du}$ roman québécois. Réflexions conceptuelles et perspectives littéraires", Globe, vol. 7, no 2, 2004, pp. 31-58. The closest precursor to the Mainmise phenomenon, however, was the Yéyé music trend in 1960s, which was accompanied by an "avalanche of translations" of American songs into French.

34. Jean-Philippe Warren, “Mainmise : Un almanach du village global”, art. cit., p. 432.

35. Mainmise, especially in its early format, adopted the psychedelic visual aesthetic common to counter-cultural magazines in the U.S., Canada and Europe and the movement as a whole, from the magazines and comics to images associated with popular rock groups, whose album cover art is often featured alongside record reviews. While images borrowed from American sources are often directly reproduced in Mainmise, Québécois comic artists and illustrators are also featured over the course of the magazine's publication history. The extent to which these artists "copied" or developed their own styles merits further study.

36. Don, “De biens tristes pensées”, Mainmise, no 23, 1973, p. 63.

37. Eric, "Regret", Mainmise, no 25, 1973. p. 7.

38. This third format, with its emphasis on local music, arts and news, and balance between alternative and popular culture, bears some resemblance to the free alternative weeklies that emerged in the mid-1980s in Montreal: the English-language Mirror (1985-2012) and Frenchlanguage Voir (1986-present). Though perhaps not a direct precursor, the later Mainmise format may have set a precedent.

39. See Hans-Jürgen Lüsebrink, "Les transferts culturels: théorie, méthodes d'approche, questionnements", in Pascal Gin, Nicolas Goyer and Walter Moser (eds.), Transferts. Exploration d'un champ conceptuel, Ottawa, Presses de l'Université d'Ottawa, 2014, pp. 33-34.

40. Stewart Brand, The Whole Earth Catalog, San Rafael, Point Foundation, 1968-1972.

41. Khal, Georges, "Les origines de Mainmise", art. cit., par. 8.

42. Christian Allègre, "Un Catalogue québécois des outils planétaires”, Mainmise, no 43, 1975, p. 72.

43. Pénélope, “Mainmise à l'assaut de San Francisco”, Mainmise, no 11, 1972, p. 74.

44. Abbie Hoffman, Woodstock Nation: A Talk-Rock Album, New York, Random House, 1969.

45. Rasa Gustaitis, Rasa, Turning On, New York, Macmillan, 1968.

46. Linda Gaboriau was a frequent contributor over the first 23 issues of Mainmise. She went on to become one of Quebec's most well-known and prolific translators, having translated more than 125 Québécois plays and novels into English. She may have contributed several translations to Mainmise, but, if so, they are not clearly credited.

47. Joanna and Timothy Leary, NeuroLogic, San Francisco, Level Press, 1973.

48. Rick Strauss, How to Win Games and Influence Destiny: A Manual for Apprentice Gods, Los Angeles, Gryphon, 1969. 
49. Joanna and Timothy Leary, Terra II: The Starseed Transmission, San Francisco, Imprinting Press, 1974.

50. Buckminster Fuller, Operating Manual for Spaceship Earth, Carbondale, Southern Illinois University Press, 1968.

51. Stewart Brand, II Cybernetic Frontiers: Both Sides of the Necessary Paradox, New York, Random House, 1974.

52. The event included workshops, film screenings, poetry readings and panel discussions. When Ginsberg was asked about his stay in Montreal, he replied: "The other night when we were speaking at the Bibliothèque nationale, I had the feeling that I was in front of 800 Jack Kerouacs who were all trying to speak at the same time... It was very impressive" (1975), "Interview d'Allen Ginsberg et William Burroughs," Mainmise, no 47, 1975, p. 8.

53. Victor-Lévy Beaulieu, "Le Québec, sa langue, pis sa contre-culture", Études littéraires, vol. 6, no 3, 1973, pp. 364-366. If Mainmise's translation efforts were not exactly resisted they were often denounced, both by readers in their letters to the editor and by other intellectuals and literary figures of the period. Philippe Haeck and Jules Duchastel, each in their own way, accused the counter-culture movement and Mainmise, in particular, of perpetuating a bourgeois ideology by promoting absolute individualism and "declared apoliticism": Philippe Haeck, "La contre-culture ou la culture révolutionnaire", Chroniques, nos 18-19, 1976, p. 12; Jules Duchastel, "Mainmise: la nouvelle culture en dehors de la lutte des classes?", Chroniques, nos 18-19, 1976, pp. 3858. Patrick Straram likewise observed: "Mainmise introduced Quebec to sociocultural values and notions of fundamental liberation; but by elevating this to an absolute, it produced another totalitarian imperialism that alienated, reified and distorted it": Claude Beausoleil and André Roy, "Entretien avec Patrick Straram, le bison ravi", HoboQuébec, nos 9-11, 1973, p. 33.

54. Lili Lemaître-Auger, "Québec électrique”, Mainmise, no 17, 1972, pp. 14-15.

55. "Après dix ans d'acide à San Francisco", Mainmise, no 12, 1972, pp. 4-5

56. "Mainmise 2," "Organe québécois du rock international, de la pensée magique et du gay savoir", Mainmise, no 2, 1970, p. 16-17.

57. Ed Richer, "Le cinéma, les garçons et le Gay Power", Mainmise, no 1, 1970, p. 170.

58. Yvonne de Maujincourt and Gilles Hughes, "Pour un Front gay [sic] à Montréal", Mainmise, no 3, 1971, pp. 186-191.

59. Carl Wittman, "A Gay Manifesto", New York, Red Butterfly Publication, Rainbow History Project Digital Collections, 1970, n.p. Online, URL: http:// www.againstequality.org/files/refugees_from_amerika_a_gay_manifesto_1969.pdf.

60. Robert Schwartzwald, "Le Front de libération homosexuel du Québec et les limites de la contre-culture", in Karim Larose and Frédéric Rondeau (eds.), La contre-culture au Québec, Montréal, Presses de l'Université de Montréal, 2016, pp. 453-486.

61. "Allen Ginsberg et les Fronts de libération gay", Mainmise, no 22, 1973, p. 60.

62. "Un ouvrage simple sur l'homosexualité", Mainmise, no 23, 1973, p. 55.

63. "Les sœurs en congrès à Los Angeles", Mainmise, no 24, 1973, p. 43.

64. Falardeau, Pierre, "Monsieur le Premier Ministre", Mainmise, no 29, 1973, p. 46.

65. Patrick Celier, "Rôle prophétique de l'homosexuel dans notre société judéochrétienne", Part I., Mainmise, no 31, 1973, p. 8, and Patrick Celier, "Rôle prophétique de l'homosexuel dans notre société judéo-chrétienne", Part II, Mainmise, no 31, 1974, p. 7. 
66. Gui Lavoie, “Un front homosexuel québécois de libération”, Mainmise, no 33, 1974, p. 18.

67. The speeches are by Tatanka Yotanka (Sitting Bull), Mahpiya-Luta, Tashunca Uitco, AdhahtsiAhush, Heraka Sapa, Ours-Ruant, Parra-Wa-Samen, Satank, Cochise, Geronimo and Heinmot Tooyalaket. The sources are not listed in Mainmise. Further research is needed to locate the original sources and languages, as well as the circumstances of their transcription into writing, and translation from Indigenous languages into French and English.

68. Christian Barrière, "Un gars et un trip à la baie Jacques", Mainmise, no 33, 1973, pp. 38-40.

69. "Structures et mythologies: Les Indiens du nord du Québec", Mainmise, no 34, 1974, p. 67.

70. “Les indiens et le péril blanc", Mainmise, no 56, 1976, pp. 36-40.

71. Harold Cardinal, The Unjust Society: The Tragedy of Canada's Indians, Edmonton, M. G. Hurtig, 1969, p. 79. Translation in French: Harold Cardinal, La tragédie des Indiens du Canada, trans. Raymond Gagné and Jacques Vallée, Montreal, Editions du Jour, 1970.

72. Raynold Lortie, “L'Indien”, Mainmise, no 28, 1973, p. 74.

73. “Just Like a Woman", Mainmise, no 2, 1970, pp. 106-125.

74. Christine L'Heureux, “Les femmes de l'O.N.F. parlent”, Mainmise, no 32, 1974, pp. 69-70.

75. Yoko Ono, “The Feminization of Society”, The New York Times, 23 Feb, 1972, p. 41.

76. Baba Ram Dass, Be Here Now, Remember, San Cristobal, Lama Foundation, 1971.

77. Carlos Castaneda, The Teachings of Don Juan: A Yaqui Way of Knowledge, New York, Ballantine, 1968.

78. Georges Khal, "Les manuels pratiques du nouveau Noé ou comment bâtir son arche en paix et chez soi”, Mainmise, no 25, 1973, p. 30.

79. Buckminster Fuller, Operating Manual for Spaceship Earth, op. cit.

80. Georges Khal, "Il était une fois des mutants qui firent Mainmise sur...", Mainmise, no 26, 1973, p. 9.

81. Charles Gosselin, "Les carnets de Noé ou comment bâtir kébek", Mainmise, no 28, 1973, pp. 38-62.

82. Normand Bourque, “Quelques 'Mainmise' au point”, Mainmise, no 2, 1970, p. 29.

83. Pénélope, "Et maintenant, Pénélope vous parle de Mainmise", Mainmise, no 1, 1970, p. 64.

84. Pénélope, "Et maintenant Pénélope vous parle de Mainmise", Mainmise, no 5, 1971, p. 19.

85. Pénélope, "Et maintenant, Pénélope vous parle de Mainmise", Mainmise, no 1, 1970, p. 9.

86. Georges Khal, "Les manuels pratiques du nouveau Noé ou comment bâtir son arche en paix et chez soi”, Mainmise, no 25, 1973, p. 30.

87. Michel Bélair, "Kessé la Kabbale. Introduction à un traité de thermo-dynamique habituellement abordé sous l'angle du mysticisme juif”, Mainmise, no 31, 1974, p. 31.

88. Michel Bélair, "Fred. Deux heures avec le "prophète-maçon de vieux Québec", Mainmise, no 34, 1974, p. 38.

89. Ibid., p. 39.

90. Pénélope, "Et maintenant, Pénélope vous parle de Mainmise”, Mainmise, no 1, 1970, p. 10.

91. Ibid. ; "De la viande. Charlebois parle de son prochain disque", Mainmise, no 25, 1973, p. 58. 
92. Gérard Bouchard, "Une crise de la conscience historique. Anciens et nouveaux mythes fondateurs dans l'imaginaire québécois", in Stéphane Kelly (ed.), Les idées mènent le Québec. Essais sur une sensibilité historique, Québec, Les Presses de l'Université Laval, 2003, p. 36. The Grande Noirceur refers to the period marked by Maurice Duplessis' tenure as Premier of Quebec from 1936-1939 and again from 1944-1959. It has been widely regarded as a period oppression and stagnation that set the stage for the Quiet Revolution.

93. The French-Canadian concept of survivance dates to the Conquest of 1760 and France's relinquishment of its North American territories to Great Britain at the close of the Seven Years' War. It became entrenched following the publication of the explicitly assimilationist Durham Report (1839) and fusing of Upper and Lower Canada in the Act of Union (1840).

94. Normand Bourque, "Quelques 'Mainmise' au point", art. cit., p. 28.

95. “Le Vaisseau spatial électronique”, Mainmise, no 11, 1972, p. 136.

96. "Le Livre du colon", Mainmise, no 22, 1973, p. 26.

97. Jean-Philippe Warren, “Countercultural Practices and Experiences in Quebec's NeoRural Communes", in Michèle Thériault (ed.), Actions That Speak. Aspects of Quebec Culture in the 1960s and 1970s, Leonard and Bina Ellen Gallery, 2012, p. 107.

98. Pénélope, "Et maintenant, Pénélope vous parle de Mainmise", Mainmise, no 1, 1970, p. 63-64.

99. Pénélope, "Et maintenant Pénélope vous parle de Mainmise", Mainmise, no 5, 1971, p. 14.

100. Charles Gosselin, "Les carnets de Noé ou comment bâtir kébek”, Mainmise, no 28, 1973, p. 38.

101. “Avant-propos", Mainmise, no 28, 1973, p. 1.

102. Paul Chamberland, “D'ici le grand changement”, Mainmise, no 44, 1975, p. 6.

103. Ibid., p. 8.

104. Jean Basile and Georges Khal, "Yin/Yang: Un entretien cyclique avec Georges Khal et Jean Basile sur la catastrophe qui attend le monde", Mainmise, no 24, 1973, p. 27.

\section{ABSTRACTS}

Published in Montreal between 1970 and 1978, Mainmise was the most important periodical associated with the emerging youth counter-culture movement in Quebec. Its editors drew inspiration from themes that formed the cornerstones of the American counter-culture movement - sex, drugs and rock n' roll - and trips to American hippy meccas like HaightAshbury in San Francisco or Greenwich Village in New York. The magazine's aesthetic was marked by an eclectic mix of typesetting, handwriting, drawings and photographs. It was also a product of translation. With access to images and texts drawn from over 200 publications (as a member of the Underground Press Syndicate), Mainmise's editors and contributors translated some of the American movement's key writings and music, adapted the psychedelic graphic styles of its comics and periodicals, and provided a hub for an alternative social network. This paper examines the evolution of Mainmise over three periods of its publication history. Integrating perspectives from translation studies and memory studies, it develops the idea of 
counter-memory as a translational phenomenon based on re-identification (the construction of alternative collective references through cultural borrowing and transfer) and retemporalization (the re-inscription of references in a remembered past or utopic future). I will first discuss the emergence of alternative collective references in post-Quiet-Revolution Quebec to then concentrate on Mainmise as a locus of transnational, counter-cultural memory and translation.

INDEX

Keywords: Mainmise, counter-culture, counter-memory, magazine culture, translation

\section{AUTHOR}

\section{CARMEN RUSCHIENSKY}

Carmen Ruschiensky holds an MA in Translation Studies and is currently completing a $\mathrm{PhD}$ in Humanities at the Centre for Interdisciplinary Studies in Society and Culture at Concordia University. Her research explores the translation and mediation of cultural memory in Quebec. Her published articles can be found in Archivaria (2017) and TTR : traduction, terminologie, rédaction (2018), and in the edited volumes Relire les revues québécoises : histoire, formes et pratiques (2021), The Routledge Handbook of Translation and Memory (2022), and Translation and the Global City: Bridges and Gateways (2022). 